\title{
PEMBELAJARAN SEJARAH SECARA DARING DI TENGAH PANDEMI VIRUS CORONA-19
}

\author{
Eka Lestari \\ NIM. 1810111220034 \\ Email: ekalestari16bjm@gmail.com \\ Program Studi Pendidikan Sejarah Fakultas Keguruan dan Ilmu Pendidikan \\ Universitas Lambung Mangkurat \\ Banjarmasin
}

\begin{abstract}
Abstrak
Pandemic COVID-19 telah mengubah berbagai aspek kehidupan manusia saat ini, khususnya dalam dunia pendidikan. Ini mengharuskan semua elemen pendidikan untuk beradaptasi dan melanjutkan sisa semester. Pembelajaran online menjadi solusi efektif untuk mengaktifkan kelas meski sekolah telah ditutup mengingat waktu dan tempat menjadi beresiko pada masa pandemic ini. Namun, teknik pembelajaran penting untuk dievaluasi sesuai dengan kondisi setempat mengingat sebaran fasilitas dan kemampuan orang tua memberikan fasilitas pembelajaran online berbeda kepada peserta didik di Indonesia. Pembelajaran online memberikan kemudahan dalam memberikan transfer informasi pada berbagai situasi dan kondisi. Ragam manfaat dari kemudahan pembelajaran online didukung berbagai platform mulai dari diskusi hingga tatap muka secara virtual. Kuncinya adalah memaksimalkan kemampuan peserta didik belajar dalam kondisi pandemic seperti ini.
\end{abstract}

Kata kunci: pembelajaran, masa pandemi, COVID-19 


\section{PENDAHULUAN}

Media sosial merupakan sebagian hasil dari kemajuan perkembangan teknologi, seiring dengan perkembangan zaman. Pada era globalisasi media sosial semakin banyak jenisnya dan berkembangnya pun sangat pesat sekali. Di era globalisasi ini banyak sekali kecanggihan pada media sosial yang menjadikan bagian yang sulit untuk dijauhkan dari kehidupan manusia apalagi dalam dunia pendidikan. Internet merupakan sebuah perpustakaan yang tanpa batas dalam pencakupannya. Media sosial memiliki ciri-ciri yakni partisipasi, perbincangan, dan keterbukaan (Tosepu, 2018). Dengan menggunakan media sosial yang berupa internet semua informasi ada dan dapat memudahkan peserta didik dalam mengaksesnya. Bahkan sudah hampir semua di negara maju maupun negara berkembang dapat memanfaatkan internet sebagai jendela informasi (Permana, 2018), (Firman, 2020).

Semua kejadian hampir diseluruh bumi ini sedang booming dengan adanya virus covid-19, terutama di Negara Indonesia yang saat ini sedang maraknya terserang virus covid-19. Virus covid-19 atau coronavirus adalah penyakit yang berasal dari Cina dan para ahli menyatakan bahwa indikasi kuat bahwa penyebab SARS, virus ini penyebab infeksi saluran pernapasan yang menyebar melalui sekresi pernapasan, kemudian hidung pada dinding saluran pernapasan bagian atas, beberapa fakta menyebutkan coronavirus ini menimbulkan banyak kematian, virus ini diduga mengalami mutasi sehingga bersifat semakin ganas. Hingga semua orang berhenti beraktifitas dan melaksanakan semua kegiatan didalam rumah. Dan tentu saja hal ini secara tidak langsung dapat mengganggu Kegiatan Belajar Mengajar di sekolah. Pelaksanaan Work from Home (WFH) ini di berbagai sekolah dilatar belakangi oleh meluasnya penyebaran virus corona disejumlah daerah. Hal ini juga dapat dikaitkan dengan hak pendidik dan juga peserta didik atas keselamatan belajar mengajar. Sebagai upaya untuk mencegah dan melindungi guru maupun siswa, beberapa pihak berwenang menetapkan kebijakan WFH untuk sementara waktu. Dalam hal ini pendidik dan siswa diharuskan untuk belajar secara online dan 
menjalankan social distancing selama terjadinya wabah corona ini guna untuk memutus jaringan virus tersebut.

\section{PEMBELAJARAN SEJARAH SECARA DARING}

Kebijakan social distancing maupun physical distancing guna meminimalisir penyebaran COVID-19 mendorong semua elemen pendidikan untuk mengaktifkan kelas meskipun sekolah tutup. Penutupan sekolah menjadi langkah mitigasi paling efektif untuk meminimalisir penyebaran wabah pada anak-anak. Solusi yang diberikan yakni dengan memberlakukan pembelajaran dirumah dengan memanfaatkan berbagai fasilitas penunjang yang mendukung. Selama masa pandemic COVID-19 pembelajaran dirumah atau online menjadi solusi melanjutkan sisa semester. Pembelajaran online didefinisikan sebagai pengalaman transfer pengetahuan menggunakan video, audio, gambar, komunikasi teks, perangkat lunak (Basilaia \& Kvavadze, 2020) dan dengan dukungan jaringan internet (Zhu \& Liu, 2020). Ini merupakan modifikasi transfer pengetahuan melalui forum website (Basilaia \& Kvavadze, 2020) dan tren teknologi digital sebagai ciri khas dari revolusi industry 4.0 untuk menunjang pembelajaran selama masa pandemic COVID-19.

Integrasi teknologi dan ragam inovasi ciri dari pembelajaran online (Banggur et al., 2018). Selain itu, yang terpenting adalah kesiapan pendidik dan peserta didik untuk berintereaksi secara online. Infrastruktur yang mendukung pembelajaran online secara gratis melalui berbagai ruang diskusi seperti Google Classroom, Whatsapp, Kelas Cerdas, Zenius, Quipper dan Microsoft (Abidah et al., 2020). Fitur Whatsapp mencakup Whatsapp Group yang dapat digunakan untuk mengirim pesan teks, gambar, video dan file dalam berbagai format kepada semua anggota (Kusuma \& Hamidah, 2020). Google Clasroom juga memungkinkan pendidik dan guru mengembangkan pembelajaran kreatif. Diskusi dan transfer pengetahuan secara face-to-face layaknya bertemu melalui beragam platform video teleconference yang banyak tersedia gratis seperti Zoom dan Google Meet. Platform tersebut menjadikan pendidik dan peserta didik untuk bertemu dan berinteraksi secara virtual dengan fasilitas pesan instan dan kegiatan presentasi (Wiranda \& Adri, 2019).

Berbagai layanan tersebut dapat dimanfaatkan sebagai penunjang transfer pengetahuan hingga diskusi terkait konten pembelajaran. Ini juga dilakukan dengan 
memanfaatkan segala sumber daya local secara nasional seperti saluran televisi untuk edukasi (Zhou et al., 2020). Di Indonesia, televisi pada saluran TVRI digunakan untuk menyiarkan konten edukasi secara nasional. Konten yang disiarkan digolongkan berdasarkan jenjang pendidikan yang sesuai dengan kurikulum di Indonesia. Variasi platform dan seumber daya yang tersedia membantu menunjang proses pembelajaran selama pandemic COVID-19. Aktifitas pembelajaran yang dapat dilakukan mulai dari diskusi, presentasi hingga pemberian tugas. Pembelajaran online melatih kemandirian belajar. Ini akan membutuhkan keterlibatan peserta didik yang lebih besar untuk meningkatkan perilaku belajar observasional. Perilaku tersebut dapat dilakukan dengan membaca, memaknai postingan diskusi dan mendiskusikan video atau konten pembelajaran (Zayapragassarazan, 2020). Ini akan membiasakan peserta didik untuk mengumpulkan dan mengelola informasi terkait tugas yang diberikan tanpa batasan ruang dan waktu. Hal ini dikarenakan pembelajaran online memungkinkan akses informasi dan pengetahuan dirumah dan dimanapun yang disesuaikan dengan kenyamanan peserta didik. Belajar online menuntut peran pendidik mengevaluasi efektivitas dan disesuaikan dengan kebutuhan belajar. Ini penting dilakukan untuk tetap memenuhi aspek pembelajaran seperti proses pengetahuan, moral, keterampilan, kecerdasan dan estetika (Dai \& Lin, 2020). Mengingat bahwa perubahan ke pembelajaran online secara tidak langsung berpengaruh pada daya serap peserta didik (Dewi, 2020). Penting untuk diperhatikan yakni komunikasi orang tua dan pendidik untuk mewujudkan kemandirian belajar peserta didik selama masa pandemic COVID19.

Ragam manfaat yang diperoleh, tentu memiliki kendala yang dirasakan pendidik maupun peserta didik dalam pembelajaran online. Kendala yang dihadapi yakni kondisi wilayah di Indonesia yang beragam menyebabkan tidak semua wilayah terjangkau oleh layanan internet dan sebaran jaringan internet yang lamban sewaktu-waktu (Khasanah et al., 2020). Ini juga memungkinkan penggunaan internet yang tinggi berpengaruh pada kesehatan peserta didik. Kendala lain yang ditemukan yakni kemampuan orang tua untuk memberikan fasilitas pendidikan online (Obiakor \& Adeniran, 2020) seperti penggunaan jaringan internet yang membutuhkan biaya (Jones \& Sharma, 2019). Permasalahan tersebut tentu harus tetap di evaluasi guna memperoleh pembelajaran yang lebih baik. Kuncinya adalah untuk melakukan pembelajaran online sesaui dengan 
kondisi setempat (Zhang et al., 2020). Hal terpenting untuk menciptakan kemandirian dan keterampilan belajar peserta didik di tengah pandemic COVID-19.

Pada dasarnya sekarang ini proses pembelajaran sejarah khusus nya di Indonesia masih menggunakan cara pengajaran yang konvensional bahkan tidak keseluruhan mengembangkan keterampilan intelektual anak. Yang seperti kita ketahui, ketika siswa ditanya mengenai pelajaran sejarah, maka kebanyakan siswa mengatakan bahwa pelajaran tersebut sangat membosan kan, karena yang dipikirkan siswa kecenderungan pembelajaran sejarah merupakan pembelajaran yang slalu menitik beratkan pada hafalan mengenai sebuah peristiwa, nama-nama tokoh yang terlibat, tahun-tahu peristiwa dan tokoh-tokot yang berpengaruh pada masa itu. Maka dari itu saya setuju dengan artikel ini (Anis, M. Z. A., Putro, H. P. N., Susanto, H., \& Hastuti, K. P. (2020). Historical Thinking Model in Achieving Cognitive Dimension of Indonesian History Learning. PalArch's Journal of Archaeology of Egypt/Egyptology, 17(7), 7894-7906.), dimana mereka ingin membuat suatu perubahan dengan model evaluasi untuk mengetahui pencapaian siswa dalam proses berpikir sejarah, agar siswa mampu berpikir tentang sejarah dengan tercapainya tujuan dari pembelajaran. Oleh karena itu dilakukan lah penelitian mengenai pengembangan model evaluasi pemikiran sejarah pada mahasiswa tingkat perguruan tinggi, yang diharapkan mampu menjadi intrumen evaluasi pemikiran sejarah dengan unsur pemenuhan keilmuan pedagogis. Berdasarkan artikel terseebut, ada 3 topik pembahasan yang di temukan pada penelitian sebelumnya, yaitu mengenai pencarian model evaluasi pemikiran nya, pengujian dari model tersebut, dan cara memenuhi kebutuhan untuk mengembangkan model pemikiran sejarah itu sendiri. Dan keberhasilan untuk system pembelajaran di perguruan tinggi memerlukan inovasi dalam kegiatan pembelajarannya untuk menggiring subjek agar berfikir secara historis, dan hal tersebut memerlukan pendekatan sistem pembelajaran yang kreatif dan system evaluasi agar proses dalam kegiatan pembelajaran berjalan dengan efektif dan afisien. Dan tercapai nya cara berpikir sejarah kepada para pelajar. Hal demikian bisa kita lakukan melalu media daring seperti zoom, google class room dan lain- 
lain agar proses pembelajaran bisa berjalan lebih efektif sesuai dengan yang harapkan.

\section{SIMPULAN}

Dengan demikian dapat kita lihat dampak positif dan negatif dari pembelajaran online yang diterapkan oleh setiap sekolah dalam menghadapi virus Corona tersebut, dalam kegiatan belajar mengajar secara online sendiri memiliki efek yang bagus terhadap pembelajaran, karena anak bisa mengenal dan belajar lewat online dan dapat memanfaatkan teknologi yang ada secara bijak dan lebih mengetahui bagaimana tata cara yang baik dalam menggunakan gadget atau media elektronik yang dapat membantu dalam pembelajaran online yang lainnya.

Tetapi disamping dampak baik tersebut memiliki dampak negatif yang lebih besar karena kegiatan belajar mengajar sendiri lebih baik dilakukan secara langsung bertatap muka dengan guru atau pendidik karena pembelajaran online tidak bisa menanamkan pendidikan yang berkarakter sosial serta pendidikan secara online juga dapat menimbulkan jiwa anti sosial karena membuat anak anak menjadi nyaman dengan dunianya sendiri dan acuh dengan keadaan sekitar, oleh sebab itu peran orang tua sangatlah penting dalam hal ini, orang tua harus dapat mengawasi anak dengan baik dalam terjadinya proses pembelajaran online karena anak sendiri masih labil dan masih sangat membutuhkan adanya bimbingan dalam menjalankan pembelajaran berbasis online agar tidak terjadi sesuatu hal yang tidak diinginkan khusus untuk anak sekolah dasar yang masih harus mendapat dampingan dari orang tua. 


\section{REFERENSI}

Abidah, A., Hidaayatullaah, H. N., Simamora, R. M., Fehabutar, D., \& Mutakinati, L. (2020). The Impact of Covid-19 to Indonesian Education and Its Relation to the Philosophy of "Merdeka Belajar." Studies in Philosophy of Science and Education, 1(1), 38-49.

Ahmad Jaelani, Hamdan Fauzi, Hety Aisah, Q. Y. Z. (2020). Penggunaan Media Online Dalam Proses Kegiatan Belajar Mengajar Pai Dimasa Pandemi Covid19 (Studi Pustaka dan Observasi Online). JURNAL IKA: IKATAN ALUMNI PGSD UNARS, 8(1), 12-24.

Anis, M. Z. A., Putro, H. P. N., Susanto, H., \& Hastuti, K. P. (2020). Historical Thinking Model in Achieving Cognitive Dimension of Indonesian History Learning. PalArch's Journal of Archaeology of Egypt/Egyptology, 17(7), 7894-7906.

Banggur, M. D. V., Situmorang, R., \& Rusmono. (2018). Pengembangan Pembelajaran Berbasis Blended Learning pada Mata Pelajaran Etimologi Multimedia. JTP - Jurnal Teknologi Pendidikan, 20(2), 152.

Basilaia, G., \& Kvavadze, D. (2020). Transition to Online Education in Schools during a SARS-CoV-2 Coronavirus (COVID-19) Pandemic in Georgia. PedagogicalResearch, 5(4).

Dai, D., \& Lin, G. (2020). Online Home Study Plan for Postponed 2020 Spring Semester during the COVID-19 Epidemic: A Case Study of Tangquan Middle School in Nanjing, Jiangsu Province, China. SSRN Electronic Journal.

Dewi, W. A. F. (2020). DAMPAK COVID-19 TERHADAP IMPLEMENTASI PEMBELAJARAN DARING DI. 2(1), 55-61.

Firman, F. (2020). Dampak Covid-19 terhadap Pembelajaran di Perguruan Tinggi. BIOMA: Jurnal Biologi Dan Pembelajarannya, 2(1), 14-20.

Jones, K., \& Sharma, R. (2019). REIMAGINING A FUTURE FOR ONLINE LEARNING.

Khasanah, D. R. A. U., Pramudibyanto, H., \& Widuroyekti, B. (2020). Pendidikan Dalam Masa Pandemi Covid-19. Jurnal Sinestesia, 10(1), 41-48. 
Kusuma, J. W., \& Hamidah. (2020). Platform Whatsapp Group Dan Webinar Zoom Dalam Pembelajaran Jarak Jauh Pada Masa Pandemik Covid 19. Jurnal Ilmiah Pendidikan Matematika Volume, 5(1).

Permana, E. P. (2018). Pengaruh Media Sosial sebagai Sumber Belajar IPS TerhadapMotivasi Belajar, Kemampuan Berpikir Kritis dan Berpikir Kreatif Siswa Sekolah Dasar. PINUS, 54-59.

Obiakor, T., \& Adeniran, A. (2020). Covid-19: Impending Situation Threatens to Deepen Nigeria' S Education Crisis. Center For the Study of The Economies of Africa.

Susanto, H., \& Akmal, H. (2018). Efektivitas Penggunaan Aplikasi Pembelajaran Berbasis Mobile Smartphone Sebagai Media Pengenalan Sejarah Lokal Masa Revolusi Fisik di Kalimantan Selatan Pada Siswa Sekolah Menengah Atas. HISTORIA: Jurnal Program Studi Pendidikan Sejarah, 6(2), 197-206.

Susanto, H., Irmawati, I., Akmal, H., \& Abbas, E. W. (2021). Media Film

Dokumenter Masuknya Islam Ke Nusantara dan Pengaruhnya Terhadap Keterampilan Berpikir Kritis Siswa. HISTORIA: Jurnal Program Studi Pendidikan Sejarah, 9(1).

Tosepu, Y. A. (2018). Media Baru dalam Komunikasi Politik di Dunia Virtual. Surabaya: CV. Jakad Publishing Surabaya.

Wiranda, T., \& Adri, M. (2019). Rancang Bangun Aplikasi Modul Pembelajaran Teknologi WAN Berbasis Android. VoteTEKNIKA (Vocational Teknik Elektronika Dan Informatika), 7(4), 2302- 3295.

Zayapragassarazan, Z. (2020). COVID-19: Strategies for Online Engagement of Remote Learners. 246, 1-11.

Zhang, W., Wang, Y., Yang, L., \& Wang, C. (2020). Suspending Classes Without Stopping Learning: China's Education Emergency Management Policy in the COVID-19 Outbreak. Risk and Financial Management, 13(55), 1-6.

Zhou, L., Li, F., Wu, S., \& Zhou, M. (2020). “School's Out, But Class's On”, The Largest Online Education in the World Today: Taking China's Practical Exploration During The COVID-19 Epidemic Prevention and Control as An Example. The Largest Online Education in the World Today, 4(2), 501-519. 
Zhu, X., \& Liu, J. (2020). Education in and After Covid-19: Immediate Responses and Long-Term Visions. 